\title{
NUMERACY SKILLS EMPOWERMENT FROM PRESCHOOL
}

\author{
Maria Lidia Mascia, Maria Chiara Fastame, Mirian Agus and Maria Pietronilla Penna \\ Department of Pedagogy, Psychology, Philosophy, University of Cagliari, Italy
}

\begin{abstract}
The development of numerical abilities was examined in 59 children aged 5 years divided into three groups: one control group $(n=15)$ and two experimental groups (pencil-and-paper mathematical training: $n=29$ : computerized mathematical training: $n=15$ ). The participants were assessed both before and after a battery of validated tests assessing numerical abilities (BIN test) and fluid intelligence (CPM test). The three groups showed similar values in the pre-test assessment regarding these two dimensions. A gain between post-test and pre-test scores was calculated; this result underlines significant differences between experimental groups and the control group in the four areas evaluated by the BIN test. This study shows the efficacy of both computer-assisted and pencil-and-paper training in enriching numerical intelligence; pencil-and-paper mathematical training seems to be more effective in some areas. This aspect leads us to reflect about this result and to deepen the research with subsequent experiments.
\end{abstract}

\section{KEYWORDS}

Early Numeracy Learning, Psychoeducational Training, Preschool, Cognitive Empowerment, Educational Technology

\section{INTRODUCTION}

A wide literature has documented that the effect of developmental factors on numeracy competence (i.e. the ability to use numerical information to perform different daily life activities, such as counting, seriation and number comparison tasks) begins in early infancy and continues along the whole life span, predicting not only academic achievements (e.g. Watt et al., 2014) but also some aspects of later life quality, such as mental health (e.g. Fastame et al., 2019).

With the early life span, there is evidence that low kindergartner numeracy performance predicts later mathematics achievement in primary school (e.g. Geary et al., 1999). Therefore, if it is crucial to identify the contribution of the concurrent psychological processes underpinning number processing, such as visuospatial working memory, processing speed and non-verbal reasoning (Jenks et al., 2012), in order to detect early possible atypical developmental trajectories of these cognitive functions, then the development of specific psychoeducational interventions enhancing numeracy skills in early childhood may favour later mathematics achievement during formal schooling (Melhuish et al., 2008). Relative to the psychological interventions designed to enrich cognitive processes in childhood, Holmes and Gathercole (2013) emphasize the contribution of so-called brain training as an educational aid to enhance the cognitive processes underpinning different academic achievements. Moreover, a further trend of research (e.g. Prins et al., 2011; Chen et al., 2013) highlighted that using cognitive interventions based on the use of new technologies is more effective than the traditional pencil-and-paper method for cognitive empowerment because videogame-like activities enhanced both cognitive function efficiency and pupil motivation.

Relative to the Italian context, there is evidence for the effectiveness of combined pencil-and-paper and computer-assisted interventions, including both visuospatial and numeracy tasks, for the empowerment of mathematics skills in kindergartners (Agus et al., 2015). Moreover, Mascia et al. (2015) trained one group of 5 -year-old children with a computer-assisted mathematical programme and a further group with the same computerized intervention combined with a pencil-and-paper numeracy programme; a third group did not receive any specific training (i.e. control group). After the end of training, compared with the control participants both trained groups benefitted from the psychoeducational interventions; however, no significant differences in terms of numeracy efficiency were found between the two trained groups. This suggests that the combination of computer-assisted and pencil-and-paper mathematical training was not more effective. 
However, to our knowledge, no studies have been conducted to test the separate impacts of similar pencil-and-paper and computerized interventions aimed at enriching mathematics skills in kindergartners.

This study was mainly aimed at examining the effect of the presentation modality (i.e. computer-assisted versus pencil-and-paper) on the enhancement of numeracy skills in 5-year-old children. Therefore, one group of kindergartners was presented with the computerized version of 'Intelligenza numerica I' training whereas another group was trained using the pencil-and-paper version. A further group of 5-year-old children was used as the control group.

It was hypothesized that pupils in the experimental groups might obtain higher scores in the assessment of numerical abilities than pupils in the control group.

\section{METHOD}

\subsection{Participants, Materials and Procedure}

Fifty-nine pupils ( 29 males, $49.2 \%$; mean age $65.8 \pm 4.03$ months) attending the last year of kindergarten in Italian schools (Sardinian area) were divided into three groups: the control group $(n=15)$ and two experimental groups (pencil-and-paper mathematical training: $n=29$; computerized mathematical training: $n$ $=15$ ). The activities aiming to enrich numerical knowledge were developed collectively during 10 weekly meetings that each lasted approximately 1 hour. The psychoeducational training consisted of activities developed by Lucangeli and colleagues (Lucangeli, Poli \& Molin 2003, 2010) in 'Sviluppare l'intelligenza numerica I' and 'L'intelligenza numerica I'. In the control group, pupils followed the classical activities proposed by their teachers. Assessment was carried out by the presentation (at pre-test and post-test sessions) of Raven's Colored Progressive Matrices (CPM: Raven, 1958) and the BIN numerical intelligence scale (Molin, Poli \& Lucangeli, 2007) to achieve a measure of the pupils' fluid intelligence and numerical knowledge. The BIN test is used to investigate four principal areas: lexical, semantic, pre-syntactic and counting. Each area is evaluated with specific activities, such as reading and writing.

\subsection{Findings}

These three groups showed similar values in the pre-test assessment regarding fluid intelligence and numerical knowledge (lexical area: K-W $\chi^{2}=2.396, \mathrm{df}=2, p=.302$; semantic area: $\mathrm{K}-\mathrm{W} \chi^{2}=1.971, \mathrm{df}=2$ $p=.373$; counting area: $\mathrm{K}-\mathrm{W} \chi^{2}=.381, \mathrm{df}=2, p=.827$; pre-syntactic area: $\mathrm{K}-\mathrm{W} \chi^{2}=1.252, \mathrm{df}=2$, $p=5.35$; CPM: K-W $\chi^{2}=3.589, \mathrm{df}=2, p=.166$ ). In order to assess the effect of training in numerical abilities, the gain was computed by applying the [(Post-test score - Pre-test score) / Pre-test score] ratio. Kruskal-Wallis (K-W) non-parametric statistical analyses were applied, using the training group as independent variable and the gains computed for each scale of the BIN test as dependent variables. The outcomes are shown in Table 1.

Results for the lexical area (i.e. assessing the ability to read and write Arabic numbers and the skill to join the number-word to the exact digit) and the pre-syntactic area (i.e, appraising the capability to link numbers to their number representation and to order several quantities) show an effective empowerment in both experimental groups. Pupils engaged in the pencil-and-paper activities show higher scores in the semantic area (i.e. evaluating the ability to associate numerical sizes, dots and Arabic digits) and the counting area (i.e. assessing the ability to recite the number-word sequence forward and backward, as well as knowledge of the order of Arabic digits from 1 to 5). This study shows the efficacy of both computer-assisted and pencil-and-paper training for enriching numerical intelligence, highlighting some differences between the experimental groups that use different training formats. 
Table 1

\begin{tabular}{|c|c|c|c|c|c|c|c|c|c|}
\hline Variable & $\begin{array}{c}\mathrm{K}-\mathrm{W} \\
\chi^{2}\end{array}$ & df & $p$ & Pairwise comparison & $\mathrm{W}$ & $p$ & $\begin{array}{c}\text { Mean } \\
\text { (SD) } \\
\text { Control }\end{array}$ & $\begin{array}{c}\text { Mean } \\
\text { (SD) } \\
\text { Pencil-and- } \\
\text { paper }\end{array}$ & $\begin{array}{c}\text { Mean } \\
(\mathrm{SD}) \\
\text { Computerized }\end{array}$ \\
\hline \multirow{3}{*}{$\begin{array}{c}\text { gain_BIN Lexical } \\
\text { area }\end{array}$} & \multirow{3}{*}{6.02} & \multirow{3}{*}{2} & \multirow{3}{*}{.049} & $\begin{array}{l}\text { Control / Pencil-and- } \\
\text { paper }\end{array}$ & 3.089 & .029 & .060 & .514 & .591 \\
\hline & & & & $\begin{array}{c}\text { Control / } \\
\text { Computerized }\end{array}$ & 3.073 & .030 & $(.303)$ & $(.717)$ & $(.750)$ \\
\hline & & & & $\begin{array}{c}\text { Pencil-and-paper / } \\
\text { Computerized }\end{array}$ & .441 & .755 & & & \\
\hline \multirow{3}{*}{$\begin{array}{c}\text { gain_BIN } \\
\text { Semantic area }\end{array}$} & \multirow{3}{*}{9.21} & \multirow{3}{*}{2} & \multirow{3}{*}{.010} & $\begin{array}{l}\text { Control / Pencil-and- } \\
\text { paper }\end{array}$ & 4.03 & .004 & .238 & .887 & .387 \\
\hline & & & & $\begin{array}{c}\text { Control / } \\
\text { Computerized }\end{array}$ & 2.29 & .105 & $(.961)$ & $(1.470)$ & $(.911)$ \\
\hline & & & & $\begin{array}{c}\text { Pencil-and-paper / } \\
\text { Computerized }\end{array}$ & -2.19 & .121 & & & \\
\hline \multirow{3}{*}{$\begin{array}{c}\text { gain_BIN } \\
\text { Counting area }\end{array}$} & \multirow{3}{*}{6.57} & \multirow{3}{*}{2} & \multirow{3}{*}{.037} & $\begin{array}{l}\text { Control / Pencil-and- } \\
\text { paper }\end{array}$ & 3.63 & .010 & .079 & 1.110 & .238 \\
\hline & & & & $\begin{array}{c}\text { Control / } \\
\text { Computerized }\end{array}$ & 2.21 & .119 & $(.627)$ & $(1.870)$ & $(.464)$ \\
\hline & & & & $\begin{array}{l}\text { Pencil-and-paper / } \\
\text { Computerized }\end{array}$ & -1.07 & .451 & & & \\
\hline \multirow{3}{*}{$\begin{array}{l}\text { gain_BIN Pre- } \\
\text { syntactic area }\end{array}$} & \multirow{3}{*}{21.12} & \multirow{3}{*}{2} & \multirow{3}{*}{$<.001$} & $\begin{array}{l}\text { Control / Pencil-and- } \\
\text { paper }\end{array}$ & 6.153 & $<.001$ & -.175 & 1.620 & 1.460 \\
\hline & & & & $\begin{array}{c}\text { Control / } \\
\text { Computerized }\end{array}$ & 5.214 & $<.001$ & $(.433)$ & $(2.460)$ & $(2.340)$ \\
\hline & & & & $\begin{array}{l}\text { Pencil-and-paper / } \\
\text { Computerized }\end{array}$ & .386 & .785 & & & \\
\hline
\end{tabular}

\section{CONCLUSION}

Literacy reflects the efficacy of our psychoeducational intervention in empowering the knowledge in numeracy learning starting from preschool. Psychoeducational intervention can be carried out both by pencil-and-paper and computerized formats (Agus, Mascia, Fastame e Penna, 2016; Mascia, Agus, Fastame e Addis, 2016). The latter training format underlines the importance that educational technology has in society today. Technology includes a set of electronic tools and applications that provide teaching materials and support cognitive processes in order to improve learning goals (Geiger, Goos \& Dole, 2015). It should be emphasized that the choice of format must always be accompanied by a study of learning based on an integrated design and usability that is functional and accessible (Penna \& Stara, 2010). We can therefore conclude that digital technology, as an indispensable presence in our society and in the life of all active users of schools, is a reality that cannot be overlooked or underestimated. It is necessary to know its potential and its criticality, and introduce it into everyday teaching in a conscious and responsible way (Sung, Chang \& Liu, 2016). However, in our study, it is necessary to underline how Italian schools are not yet prepared for the use of educational technology; in particular, this is evident in the lack of adequate and recent digital tools. Nowadays children use increasingly updated multimedia tools (Silverman, Kim, Hartranft, Nunn \& McNeish, 2017); in future studies it would be interesting to let the child use not only the computer but also videogames in order to enhance numeracy with greater interactivity. In this way we can also improve learning motivation and performance, for example, by using the touch-screen tablet application (Kamaruzaman, Nor \& Azahari, 2016).

\section{ACKNOWLEDGEMENT}

The authors would like to thank the schools and the children who participated in the study. 


\section{REFERENCES}

Agus, M., Mascia, M. L., Fastame, M. C., \& Penna, M. P. (2016). Difficoltà matematiche: percorsi di potenziamento delle abilità numeriche e visuo-spaziali. Psicologia dell'educazione, 2, 29-37.

Agus, M., Mascia, M. L., Fastame, M. C., Melis, V., Pilloni, M. C., \& Penna, M. P. (2015). The measurement of enhancement in mathematical abilities as a result of joint cognitive trainings in numerical and visual-spatial skills: A preliminary study. In Journal of Physics: Conference Series (Vol. 588, No. 1, p. 012041). IOP Publishing.

Chen, Y., Lin, C., Wei, T., Liu, C., \& Wuang, Y. (2013). The effectiveness of multimedia visual perceptual training groups for the preschool children with developmental delay. Research in Developmental Disabilities, 34, 4447-4454.

Fastame, M. C., Manca, C., Penna, M.P., Lucangeli, D., \& Hitchcott, P.K. (2019). Numeracy Skills and Self-Reported Mental Health in People Aging Well. Psychiatric Quarterly. doi: 10.1007/s11126-019-09655-y

Geary, D. C., Hoard, M. K., \& Hamson, C. O. (1999). Numerical and arithmetical cognition: Patterns of functions and deficits in children at risk for a mathematical disability. Journal of Experimental Child Psychology, 74, $213-239$. doi:10.1006/jecp.1999.2515

Geiger, V., Goos, M., \& Dole, S. (2015). The role of digital technologies in numeracy teaching and learning. International Journal of Science and Mathematics Education, 13(5), 1115-1137.

Holmes, J., \& Gatherchole, S. E. (2013). Taking working memory training from the laboratory into school. Educational Psychology: An International Journal of Experimental Educational Psychology. doi: 10.1080/01443410.2013.797338

Jenks, K. M., Van Lieshout, E. C. D. M., \& De Moor, J. M. (2012). Cognitive correlates of mathematical achievement in children with cerebral palsy and typically developing children. British Journal of Educational Psychology, 82, 120-135. doi:10.1111/j.2044-8279.2011.02034.x

Kamaruzaman, M. F., Nor, H. M., \& Azahari, M. H. H. (2016). Using touchscreen technology to support basic numeracy learning process for high functioning children with autism. The Turkish Online Journal of Educational Technology, 632-639.

Lucangeli, D., Poli, S. \& Molin, A. (2003). L’intelligenza numerica, Edizioni Erickson. Lucangeli, D., Poli, S. \& Molin, A., 2010. Sviluppare l'intelligenza numerica I, Edizioni Erickson.

Mascia, M. L., Agus, M., Fastame, M. C., \& Addis, A. (2016). Enhancement in Mathematical Abilities: A System Approach. Towards a Post-Bertalanffy Systemics. SE-25 Contemporary Systems Thinking ed G Minati, MR Abram and E Pessa.

Melhuish, E. C., Phan, M. B., Sylva, K., Sammons, P., Siraj-Blatchford, I., \& Taggart, B. (2008). Effects of the home learning environment and preschool center experience upon literacy and numeracy development in early primary school. Journal of Social Issues, 64(1), 95-114.

Molin, A., Poli, S. \& Lucangeli, D. (2007). Batteria Intelligenza Numerica 4-6 [Battery for Numerical Intelligence], Edizioni Erickson.

Penna, M. P., \& Stara, V. (2010). Opinions on computers, and efficacy of a computer-based learning: A pilot study. Education and Information Technologies, 15(3), 181-204

Prins, P. J., Dovis, S., Ponsioen, A., Ten Brink, E., \& Van Der Oord, S. (2011). Does computerized working memory training with game elements enhance motivation and training efficacy in children with ADHD?. Cyberpsychology, behavior, and social networking, 14, 115-122.

Raven, J.C. (1958). Guide to using the Coloured Progressive Matrices, Oxford, England: H. K. Lewis \& Co

Silverman, R., Kim, Y. S., Hartranft, A., Nunn, S., \& McNeish, D. (2017). Effects of a multimedia enhanced reading buddies program on kindergarten and Grade 4 vocabulary and comprehension. The Journal of Educational Research, 110(4), 391-404.

Sung, Y. T., Chang, K. E., \& Liu, T. C. (2016). The effects of integrating mobile devices with teaching and learning on students' learning performance: A meta-analysis and research synthesis. Computers \& Education, 94, 252-275.

Watts, T. W., Duncan, G. J., Siegler, R. S., \& Davis-Kean, P. E. (2014). What's past is prologue: Relations between early mathematics knowledge and high school achievement. Educational Researcher, 43(7), 352-360. 